\title{
OBITUARIES
}

\section{Prof. E. G. Richardson}

Edward Gick Richardson, who died on March 31 at the age of sixty-three, was well known, not only in Great Britain, but also internationally, for his work in acoustics and ultrasonics.

He took the degree course in physics at East London (now Queen Mary) College, graduating during the First World War. He then served in the Royal Air Force (Balloon Section), which no doubt initiated his life-long interest in aerodynamics and meteorology. After a short period as a grammar school master, he undertook research at East London College under Prof. C. H. Lees. About two years later he was appointed a lecturer at University College, London, and during the next seven years his research work in acoustics, recognized by the award of a D.Sc., firmly laid the foundation of his subsequent reputation. In 1931 he moved to King's College, Newcastle upon Tyne, where he spent the rest of his life; he was made a reader in 1943, and in 1956 a chair in acoustics was created for him.

Richardson's research achievement was so extensive and diverse that no brief summary is possible. It must suffice to say that he published some ninety papers on a wide variety of topics, including, besides acoustics and ultrasonies, liquid jets and suspensions, viscosity, hot-wire anemometry and viscometry, atmospheric turbulence, relaxation processes and fish locomotion. In acoustics he made notable contributions to many branches; among these the best-known are probably the absorption of sound in vapours and narrow tubes, phonetics and speech analysis, and xolian, edge and transient tones. In later years he turned his attention to ultrasonics, with special reference to absorption and dispersion. In these researches he was often assisted by students, many of them from overseas, who owe much to his help and encouragement. His experimental work was characterized by directness of attack and economy of means, and he was particularly interested in new lines of investigation. He opened up many of these, leaving others to explore the territory which his work had made accessible.

In addition to his research work, Richardson found time to write upwards of a dozen books, including several compilations which he edited or to which he contributed sections. The most widely known are probably "Sound" (a very popular textbook), "The Acoustics of Orchestral Instruments", "Acousties for Architects" and "Physical Science in Art and Industry". He wrote fluently and well, with an admirable clarity of expression and an easy mastery of his subject. He was English editor of the international journal Acustica, in the founding of which he played a prominent part.

$\mathrm{He}$ received numerous invitations to lecture abroad, and did so in the United States (several times), Canada, India and most countries of Europe. He was visiting professor of physies at the University of Cairo for a term in 1947, and a Leverhulme Fellow during 1955-57. During the Second World War he served as scientific adviser from early 1940, first in the Admiralty (Mine Design Department) and later in the Air Ministry (Royal Aireraft Establishment and Helensburgh). After returning to King's College he carried out various research contracts for these Ministries.

Although Richardson's primary interest was research it was by no means his only one, for he was an accomplished musician, a dedicated eyclist, and an indefatigable member of the College Country Dancing Club. He played both piano and organ well, and for many years travelled between Durham and Newcastle twice daily on Sundays (some sixty miles in all) in order to sing in the Cathedral choir. $\mathrm{He}$ was a deeply religious man, although none but his closest friends would be aware of this, for he was somewhat shy and reticent by nature. Nevertheless, his sterling qualities of modesty, sincerity and kindliness were apparent to all who knew him, and endeared him the more the better one knew him. His sudden death was a great shock to all his friends; they will long bear him in affectionate memory.

W. E. Curtis

\section{Dr. John Duckworth}

The sudden death on April 11 of Dr. John Duckworth, head of the Applied Biochemistry Department of the Rowett Research Institute, Aberdoen, has robbed the science of food and agriculture of an outstanding investigator.

Born in Manchester but educated in Canada, and in the course of his life conducting research in Canada, Trinidad and Guatemala, he spent about a quarter of a century in the service of the Rowett Institute at Aberdeen. He obtained his original training at the Ontario Agricultural College, Guelph, and took the degree of B.S.A. at the University of Toronto. He next spent a year with Lever Brothers, Ltd., in Toronto, as analytical chemist, and another year with the same firm's economics section studying production efficiency. In 1931 he became assistant. to the professor of chemistry at Macdonald College, McGill University, where he carried out research on the blood chemistry of cattle afflicted with genital disease, and on contagious abortion in eattle.

In 1933, Dr. Duckworth came to the Rowett Institute, where he investigated the relationship of nutrition to pathological conditions in farm animals. $\mathrm{He}$ also worked on the partition of serum calcium and the factors affecting it. The object was to estab. lish a closer relationship between the blood picture and the evidence of certain types of disease, such as milk fever and rickets, in farm stock. The latter work was incorporated into a thesis, for which the University of Aberdeen awarded him the degree of D.Sc.

Later he investigated magnesium metabolism in animals, and the influence of fibre in the diet on the utilization of protein and calcium. He collaborated in work on problems connected with both human and animal nutrition, for example, the utilization of phytic acid phosphorus in oatmeal by men and farm animals.

In April 1944 he was appointed senior lecturer in the Agricultural Department of the Imperial College of Tropical Agriculture, Trinidad. There he developed courses of instruction in animal husbandry, and created a nutrition laboratory for investigation of the 
value of various feeding stuffs under tropical conditions.

In September 1946 he returned to the Rowett Institute, and three years later became head of the Department of Applied Biochemistry. His work concerned protein and vitamin requirements, energy needs and metabolism, and mineral metabolism and requirements. $\mathrm{He}$ also developed chemical tests which might be correlated with the biological value of proteins. With Mr. N. W. Pirie, of Rothamsted Experimental Station, biological tests had been made on leaf protein for non-ruminants.

Duckworth was responsible, with the Institute's $\mathrm{X}$-ray Section, for developing a mobile $\mathrm{X}$-ray unit for the outdoor study of hill sheep in relation to calcium and phosphorus requirements. In his Department the role of copper in the ruminant was also under investigation, and much progress was being made in the elucidation of this problem.

In 1954, Dr. Duckworth was elected a Fellow of the Royal Society of Edinburgh, and in 1955 was one of four British scientists who attended a symposium of Europe's leading agricultural research experts in Rome, sponsored by the Pfizer Agricultural Research Institute of America, for discussion of research into the use of antibiotics and other new growth factors in animal nutrition. Later in the same year, he was one of three British experts invited to an international conference in Washington on the same subject.

From August 1956 until August 1957, he was seconded to the Food and Agriculture Organization of the United Nations and the United Nations Children's Fund, to assist the Governments of Costa Rica, El Salvador, Guatemala, Honduras, Nicaragua and Panama on food and nutrition policy. With Señorita E. Musmanno of Argentina, he collected statistics of the countries' food production, which showed that between 6 and 10 per cent of their population were dependent on outside sources of food supply. If one took into account the rate of growth of the population, it appeared to be necessary to double food production in the next twenty-five years, and to alter the balance between cereal and livestock production in favour of the latter. Due account was taken of the actual situation in the area : for example, cattle and sheep raising was to be based on native stock feeding on grass, rather than on imported stock eating concentrate feeding stuffs, at least in the early stages. The need was stressed for modern factories for milk and meat products. Almost his last task was to check the Spanish edition of their second report on the area.

Dr. Duckworth was an enterprising yet meticulous experimenter, a skilled statistician and planner, an arresting and clear expositor of his researches, and one who knew the agricultural industry as few others. $\mathrm{He}$ was a lively conversationalist and good pianist. $\mathrm{He}$ is survived by his wife, and a son and daughter.

D. P. Cuthbertson

\section{Prof. K. W. Szarski}

THE death of Prof. Kasmierz Witalis Szarski on January 18 prematurely severed a life of great service to zoology and Polish universities. He was born in Vienna in 1904 and on the family's removal to Lwöw attended school and the University there. He took his doctorato, and seven years later (1939) became docent in comparative anatomy. Soon afterwards the Russians occupied the University and demoted the staff. Later, under Nazism, academic work ceased, but by acting as hosts for lice used in preparing Prof. Weigl's anti-typhus vaceine, Szarski and colleagues slightly eased impoverishment and received certification as persons usefully employed. Afterwards he and his wife were arrested in Warsaw, but by mere chance escaped transportation to Nazi concentration camps and secured release, he being directed to vitamin investigations.

When war ended, Szarski became professor of comparative anatomy at Wroctaw, the new setting for the University of Lwöw--Polish no longer. Amid the devastation of Wroclaw half the zoological institute lay ruined and in its and the University's rehabilita. tion Szarski played a leading part, particularly as pro-rector and rector (1954-59).

Szarski was a born naturalist. His early researches related principally to developmental anatomy : three long papers on the urogenital systems of mice being authoritative. His post-war work mainly comprised ornithology and translation. His account of the birds adopting residential niches in the mountainous ruins of Wroclaw is fascinating. Freed from rectorial labours, he turned eagerly to study the avian brain-promising work cut short by his death. His comprehensive learning in zoology and his command of Slav and European languages-especially English, French and German, fitted him perfectly as counsellor, editor and translator in many professional capacities. His notable translations, with scholarly commentaries, comprise Darwin's "Voyage of the Beagle" (two editions) and Darwin's and Wallace's historic essays on natural selection (Linnaean Society of London). He was deservedly honoured when chosen to deliver the Darwin Centenary Lecture to the 1959 Polish Zoological Congress in Cracowpractically his last service to science.

Szarski was small and delicate-looking; of great culture, wit, sensitivity and charm; unpretentious ; of highest integrity, with an over-riding sense of duty that over-taxed his strength. He had courage : during the Warsaw rising a young insurgent refugee to Szarski's lodging owed his life to Szarski's bluffing of a Luftwaffe search-party. $\mathrm{He}$ won friendship everywhere: his students and colleagues speak of him as truly 'nieodzalowany' (never to be sufficiently mourned).

Two recent working visits to England gave Szarski renewed inspiration; in Poland British zoologists have profited by his collaboration and enjoyed the bright hospitality of Pani Szarski, himself, and their young daughter, in their modest flat high above the Oder.

In preparing this notice $\mathrm{I}$ am indebted to Mr. W. Rybotychi of London, Prof. Sembrat of Wroclaw and Prof. Henryk Szarski, rector of the University of Torun.

A. D. Peacock

\section{Prof. Ramesh Chandra Ray}

Ramesh Chandra Ray was born in 1890 and took the degree of M.Sc. from the Presidency College, Calcutta, in 1911. He was one of the first students of the Indian Institute of Science, Bangalore, where he worked with Travers on boron compounds formed by the decomposition of magnesium boride. In 1915 he was appointed professor of chemistry at Patna Colloge and, after the War, joined Donnan's laboratory at University College, Isondon, where he 